sum maxillingua (Le Sueur), in the Delaware basin. It may be of interest to know that Exoglossum also occurs east of the Delaware basin. I caught one in 1899, in Peckman's Brook where the Morris Canal crosses the brook near Little Falls, Passaic Co., N. J. If Exoglossum is not indigenous to the Passaic basin it may have reached there from the Delaware River viâ Musconetcong River and Lake Hopatcong. This lake is the summit feeder of the Morris Canal. The fish lived for many months in an aquarium. It has the feeding habits of the suckers and remains mostly near the bottom.

Eugene SMith.

Hoвoken, N. J.

\section{SPECIAI ARTICLES.}

DISCOVERY OF THE COMANCHE FORMATION IN SOUTHEASTERN COLORADO. ${ }^{1}$

During a visit to the Two Butte in Prowers County, Colo., some time ago, I found that a small local uplift east of the butte reveals the Comanche formation filled with characteristic Gryphoea corrugata. The locality is on the main, or South Butte Creek, four miles westnorthwest of the old town of Albany, or five miles east-northeast of the Two Butte. To the east and west the low bluffs in the valley consist of Dakota sandstone rising gently towards the Two Butte laccolith and the general anticline extending north and south in the southeastern portion of Prowers County. The Comanche beds are exposed just southwest of Mechling's Ranch in a small local anticline and they extend for some distance along the south side of the creek, in low bluffs capped by Tertiary deposits. The lowermost member appearing is a dark shale, more or less sandy, grading upward into a friable, brown sandstone, in part calcareous. The fossils occur in great abundance in the sandstone and sparingly in the dark shale. Owing to overlap of Tertiary sands and gravels, the precise relation to the Dakota sandstone is not clearly revealed, but it is apparent that the Comanche beds lie a very short distance below the main Dakota ledges appearing to the eastward, al-

${ }^{1}$ Published by permission of the director of the U. S. Geological Survey. though probably separated by some dark, nonfossiliferous, sandy shales which lie at the base of the Dakota cliffs in a gorge extending eastward. Probably the Red beds lie at no great distance below, but they do not appear in the immediate vicinity. A few miles west, about Two Butte, the Red beds, with their capping of Exeter sandstone, and included limestone, are extensively exposed. Down stream a short distance, east of Two Butte, the Exeter sandstone is seen to be overlain by shales and limestone of typical Morrison formation, in turn capped by Dakota sandstone. No traces of Comanche beds were found in this vicinity. It was hoped that the relations of the Morrison and the Comanche formations could be ascertained in this general region, but, owing to the apparent failure of the former to reappear in the uplift near Mechling's Ranch, no evidence was obtained on this point.

In December, 1902, Mr. Willis T. Lee gave the Geological Society of America an account of the extension of the Morrison formation down the Cimarron Valley to Exeter, Oklahoma, and the discovery of a low anticline ten miles farther east, in which the Dakota sandstone is underlain by fossiliferous $\mathrm{Co}$ manche beds.

Another item of interest which I observed in the vicinity of Two Butte uplift was the occurrence of oyster shells in considerable numbers in the Dakota sandstone on Butte Creek just below the Downing Ranch, three and a half miles due east of Two Butte and constituting a ten-foot bed a half mile southeast of Pilleau's Ranch on the headwaters of the North Fork of North Butte Creek, five miles north by east of Two Butte.

N. H. Darton.

\section{U. S. Geological Survey.}

SOME OF THE RESULTS OF THREE YEARS' EXPERIMENTS WITH CROWN GALL. ${ }^{1}$

The diseases ordinarily classed as crown gall are found on the following plants: almond, apple, apricot, ash, blackberry, chestnut, cherry, grape, hop, oak, peach, pear, plum,

\footnotetext{
${ }^{1}$ Summary of a lecture given at the annual meeting of the American Association of Nurserymen at West Baden Springs, Ind., June 15, 1905.
} 